\title{
Challenges for the Russian Foreign Policy - the Lesson of the Georgian Conflict
}

\author{
Jacek Wieclawski \\ Department of International Political Relations, Lazarski University \\ Warsaw, Poland \\ Tel: 48-22-649-7379 E-mail: j.wieclawski@poczta.onet.pl
}

Received: February 27, $2011 \quad$ Accepted: March 20, $2011 \quad$ doi:10.5539/ass.v7n8p12

\begin{abstract}
This article considers the implications of the Russo-Georgian conflict for the foreign policy of Russia, focusing on two important issues - the challenges that Moscow is going to face on the area of the Commonwealth of Independent States as well as the Russian relations with the West. Considering the consequences of the Russian intervention in Georgia for the Kremlin's policy on the CIS area the analysis points out the resistance of the Commonwealth's members as well as new challenges Russia is going to face together with the growing activity of other regional powers, including China and Beijing's interests on the area. The article refers at the same time to the Western problems with a cohesive response to the policy of Russia and determinants of post-war Russia's relations with the European Union and the United States, including determinants and prospects of the Western-Russian normalization.
\end{abstract}

Keywords: Russia, The Russo-Georgian war, Russian foreign policy, Russian-Western relations, CIS, Post-Soviet Central Asia

\section{Introduction}

The idea of great-power Russia coming back to its "adequate" international position has become a principal aim of the Russian foreign policy during the presidency of Vladimir Putin. In fact, a gap between the rhetoric and the will to act has significantly been decreased during the Putin's presidency and Russia has been striving to highlight its international position and prestige, especially on the territory of the Commonwealth of Independent States (CIS). The war in Georgia has illustrated that Moscow is determined to carry out its foreign policy aims irrespective of methods it may require.

Many observers have been indicating that the Russian intervention in Georgia has had its broader aims to consolidate the Russian influence over the post-Soviet area of the CIS. The author's conclusion is that in the short perspective the Russo-Georgian conflict has indeed strengthened the position of Russia on that area yet the Russian victory has certainly not been full and spectacular and Moscow is going to face the resistance of many CIS members. Moreover, Kremlin is going to face growing activities of other regional players and first of all the policy of China developing its economic relations with post-Soviet Central Asia.

The war in Georgia has at the same time indicated limited effectiveness of the Western diplomatic pressure on Moscow as well as Western difficulties in a more decisive response. Moscow has dismissed US and European warnings of possible sanctions and after a short period of increased tensions both sides decided to come back to "business as usual" contacts. Nevertheless, despite the clear benefits from the cooperation, one of the aims of this article is to point out that Russia's determination to support the Western powers in solving the global problems has not always been obvious and the West would still face serious troubles in formulating cohesive response once another Georgian-alike crisis happened.

The issues of the Russo-Georgian conflict have so far been broadly commented in the literature and it is not the aim of the article to debate over all the consequences of the August war. There are however some aspects of the conflict that are still valid and crucial for the future of the Russian-Western relations as well as for the foreign policy of Russia - to include the problems of the effectiveness of the Western policy towards Moscow as well as the challenges Russia is going to face on the territory of the CIS. The article is going to address them. It is divided into three parts and the general considerations concerning the implications of the Georgian conflict are 
followed by two parts focused on the issues of the CIS and Russo-Western relations. The aim of the article has certainly not been to contest the idea of the Western-Russian cooperation yet after the Russo-Georgian war any further cooperation should be based on the lesson learned by both sides and in the case of the West the problems with the formulation of more cohesive policy towards Moscow have not disappeared together with the "reset" of its relations with Russia.

\section{International Implications of the Russian-Georgian War - general remarks}

The report on the August 2008 war in Georgia prepared by the independent fact finding mission has pointed out that both sides, Georgia and Russia, share responsibility for the conflict. In the case of Russia the fault was provoking it and clearly overreacting while Georgia should be blamed for launching the attack on the rebel provinces and thus initiating the war (Independent International Fact-Finding Mission, 2009). Although both sides have been trying to take advantage of the report's conclusions David Kabadze and Marina Vashakmadze, analyzing the conflict for the Radio Free Europe/Radio Liberty (RFE/RL), note that the world news headlines accompanying the report have usually highlighted the Georgia's fault, thus contributing to Moscow's victory in the Russian-Georgian propaganda struggle following the warfare (Kabadze \& Vashakmadze, 2009; Nichol, 2009).

The president Saakashvili's role in initiating the warfare is not disputable as it is not the overreacting scale of the Russian intervention that did not stop in the rebel Abkhazia and South Ossetia and struck the ethnic Georgian territory. The problem, however, is much broader and it seems clear that one of the most important Moscow's aims has been to demonstrate that the post-Soviet area of the Commonwealth of Independent States remains a sphere of Russian "privileged interests" and Kremlin doesn't wish any foreign presence there without a Russian consent. Analysts of the Warsaw's Centre for Eastern Studies indicate in this context that Russia has been losing its influence on the area of the CIS together with diversification of political, economic and military contacts of the countries in the region as well as growing US engagement in independent of Russia transit routes for Caspian oil (Strachota, 2008). The war in Georgia has reversed this tendency, at least for some time, and Moscow has gained momentum to take over the political initiative in the region. Similarly, Svante E. Cornell, Johanna Popjanevski and Niklas Nilsson indicate quite clearly that despite the aim to "punish" Tbilisi for its pro-Western foreign policy the purpose of the Russian intervention has reached far beyond the case of Georgia with an aim to confirm the Russian primacy over the area of the CIS and inability of the West to prevent it (Cornel, Popjanevski \& Nilsson, 2008).

The reactions of the West have indeed been cautious and both the United States and the European Union have appeared unwilling or unable to react to the Russian intervention in Georgia more decisively. The European Union was finally able to take a common position, yet the attitudes of the EU members have not necessarily been common - confronting the Western European cautiousness and East-Central European attempts to engage in support for Tbilisi. The United States, developing its contacts with Georgia before the war, did not decided to respond strongly enough to stop the Russian intervention, disappointing the Georgian expectations of Washington's deeper engagement in Tbilisi's security and defense. Thus, the US and the EU reactions have in fact been an illustration of limited efficiency of the Western diplomatic pressure on Moscow.

On the contrary, the Western criticism following the war in Georgia has not weakened the Moscow's assertive and neo-imperial rhetoric. Russia has been demonstratively ignoring the warnings of the West and Kremlin has decided to stress its independent role on the international scene. To this end Russia has intensified its contacts with selected Latin American countries, and first of all Venezuela, promising them the Russian economic and political support as well as military cooperation (Sindelar, 2008). One of the aims of this demonstration has been to warn Washington that any American intervention in the Russian sphere of "privileged interests" on the area of the CIS may be reciprocated by Moscow's engagement in cooperation with countries close to the US borders and reluctant to the US hegemony, like Venezuela and Cuba. Russia has at the same time been declaring some ambitious plans to modernize its military forces, to develop its space technology, and to expand its interests on the Arctic area (Pannier, 2009a; OSW Eastweek, 2008; OSW Eastweek, 2009).

The hesitant reactions of the West have contributed to growing fears among the countries in the CIS and their attempts not to provoke Moscow. Roman Muzalevsky indicates in this context that despite the aim to "punish" Tbilisi one of the main Moscow's aims while intervening in Georgia has been to warn other CIS countries and to show them clearly "where allegiance should be (...)" (Muzalevsky, 2009). Thus, the Western powers have lost a lot of their credibility in the eyes of the CIS states (OSW Eastweek, 2008; OSW Eastweek, 2009), at least for some time. Yet despite the fears none of the countries in the region has decided to recognize the two breakaway Georgian provinces - Abkhazia and South Ossetia. It has reflected the lack of regional support for Russian 
methods used in Georgia and Lincoln Mitchell has clearly indicated that unilateral recognition of Abkhazia and South Ossetia should not be seen as a Russian diplomatic triumph (Mitchell, 2009). Nevertheless, the lack of international recognition has not prevented Russia from tightening its ties with the two breakaway Georgian provinces. Moscow signed defense agreements with both and it has actually taken control over their security. Kremlin has also declared plans to build new military bases there, including the naval base in the Abkhazian port of Ochamchire which may be crucial for the Russian interests on the area of Black Sea. Although the provinces differ slightly in the visions of their "independence", with more hesitant Abkhazian attitude towards the unification with Russia (Nichol, 2009), it seems clear that the political existence and security of both depends directly on support and protection from Moscow.

The Georgian crisis has at the same time sharpened the "battle" over the Caspian oil and gas transit, including the rivalry between the Nabucco and South Stream pipeline projects. The war has for some time questioned the Georgia's role as a stable element in the Western plans to support independent of Russia Caspian transit routes. This, in turn, has helped Moscow to promote its own transit plans (South Stream) while discrediting those disadvantageous for the Russian interests (Nabucco). Furthermore, Russia has been trying to take over a political initiative in South Caucasus aimed at weakening the Western influence there. Taking advantage of the US declining role in the Caspian region Moscow has increased its activity on the area striving for strengthening its political and economic position there. One of the key elements of the Russian game has become the question of Nagorno-Karabakh and Moscow's will to solve the conflict according to the Russian rules as well as to become a main guarantor of a potential compromise. Moscow's decision to push for the solution of the conflict has been a new feature in the Russian foreign policy as Russia has for many years been interested in keeping the conflict "frozen" (Gorecki, 2009).

On the other hand Russian intervention in Georgia and weakening position of the United States in Southern Caucasus and Central Asia have activated other regional powers having its interests on the area the CIS - mainly China and (to some extent) Turkey. They have been cautious not to directly contradict the Russia's policy there but they have taken advantage of Moscow's focus on relations with the West to promote their own economic and political interests (Strachota, 2008). In the case of Ankara, Turkey has generally been willing to respect the Russian interests in the Caspian region and to accept the new Russian engagement in solving the Nagorno-Karabakh conflict, considering normalization of its own relations with Armenia (Falkowski, 2009). Both Russia and Turkey have declared some long-term energy cooperation projects, including the new pipeline and the first Turkish nuclear power plant to be built with the Russian assistance, and Ankara's decision to allow the Russian-sponsored South Stream pipeline to cross the Turkish exclusive economic waters on the Black Sea (and thus to increase the South Stream chances in its competition with the EU-sponsored Nabucco) has contributed to a possibility of the Turkish-Russian tactical rapprochement in the region (Blua, 2010; Recknagel, 2009; Whitmore, 2010).

In the case of China, however, similar tactical rapprochement has been much less likely and Chinese activity on the area of post-Soviet Central Asia has become a subject of growing Moscow's anxiety, despite the Russo-Chinese rhetoric of cooperation. Beijing has itself been deeply interested in a stable access to Central Asian natural resources and China has been slowly but effectively building its economic ties with the countries of the region. Although Beijing has also been interested in the energy cooperation with Moscow, to be reflected by the Skovorodino-Daqing pipeline, and both Russia and China have been talking about the coordination of their policies towards the United States, the stronger position of China in post-Soviet Central Asia becomes difficult for Russia with a potential collision of both countries' interests (RFE/RL News, 2009a).

As a result, the war in Georgia has clearly illustrated that the growing assertiveness in the Russian foreign policy during the second presidential term of Vladimir Putin has not been an occasional phenomenon but a strong tendency continued by the Medvedev - Putin tandem. Intervening in Georgia Moscow has again indicated that it considers the CIS as the area of its "privileged" interests. To confirm this Russia has decided to risk worsening of its relations with the West and Kremlin has apparently assumed that the Western countries would not sacrifice their previous network of contacts with Moscow for Georgia.

The victory of Moscow, however, has not been spectacular. The Russo-Georgian war has contributed to growing anxiety among the countries on the post-Soviet area of the CIS trying to establish closer ties with other, non-Western but also non-Russian, regional players - and mainly with China. Besides, it seems that intervening in Georgia Moscow has underestimated some "softer" consequences of the intervention, including the lost of the country's international image and possible economic consequences the lost image may bring about. Stephen J. Blank points out in this context that prime minister Putin's believes that the costs of the Russian intervention in Georgia would be negligible have soon appeared false. Intervening in Georgia Russia won the war tactically yet 
it has soon appeared that the long-term strategic losses, including those of economic nature, would be much more serious (Blank, 2008).

In fact, quite surprisingly for the Russian governing elite the intervention in Georgia generated a massive outflow of capital from the Russian market resulting in a huge drop of indexes on the Moscow Stock Exchange and depreciation of the Russian ruble. The outflow reached about $\$ 130$ billion at the end of 2008 and Russian attempts to stabilize ruble largely failed (Sindelar, 2009). Having this in mind it seems that the world economic crisis and its impact on the Russian economy have contributed to mitigation of the Moscow's great-power rhetoric no less than the Western political pressure. As a result, and irrespective of its previous rhetoric, Moscow has appeared to be more willing to positively respond to President Obama's concept of the "reset" in the Russo-American relations, declaring its readiness to support Washington in solving some crucial international problems as long as the United States would be ready to "respect Russian international interests" (Tsygankov, 2009).

\section{Challenges for the Russian foreign policy on the area of the CIS}

The post-Soviet area of the Commonwealth of Independent States has always been crucial for the Russian foreign policy and Moscow has treated it as the zone of its "privileged" interests. To keep the countries of the CIS in the Russian orbit of influence Moscow has initially been using political and military methods, yet the limited effectiveness of the "hard power" instruments has inclined president Putin to reach for the economic ones (Nygren, 2007), including the "energy pressure" and Russia's reluctance to foreign contacts of the countries of the CIS. Thus, any attempts of economic or political cooperation of Azerbaijan, Uzbekistan or Ukraine with other world powers have usually not been welcomed in Moscow.

Although the war in Georgia has illustrated that Moscow is willing to use the "hard power" again, the economic instruments have remained the leverage in the hands of Russia. The world economic crisis has hit the Russian economy seriously yet in the case of many CIS members the crisis has struck them much more deeply than Russia. Thus, despite its own economic problems, Moscow has tried to take advantage of this opportunity to additionally subordinate the CIS countries by offering them a financial support but expecting some political concessions instead. Having in mind the dramatic drop in the Russian financial reserves the readiness to spend additional billions of dollars to this end may illustrate Moscow's determination to strengthen its position on the area of the CIS. As a result, Russia has decided to assign around \$2 billion for stabilization credits and investments in Kyrgyzstan, to grant \$2 billion loan for Belarus as well as \$500 million for Armenia.

The Moscow's expectations as to the partners' political concessions, however, have been high (Kononczuk, 2009). The most symptomatic in this regard was the Kyrgyz president Bakiev's February 2009 decision to close the US base at the Manas airport, used so far to supply the US troops in Afghanistan. It has been widely considered that the decision taken after the Kyrgyz loan negotiations with Russia was a result of Moscow's pressure as Russia has for a long time been interesting in reducing the US presence in Central Asia. Although the complete victory of Russia was finally limited by the Kyrgyz-US last minute June 2009 accord to prolong the US presence in Manas (Pannier, 2009b) yet some analysts suggest that Russia soon reciprocated this move by its assistance in ousting president Bakiev during the April 2010 internal riots in Kyrgyzstan (Karmanau, 2010).

Despite its pressure in bilateral relations with the CIS members Russia has been trying to revive Commonwealth's collective structures of cooperation and security. The idea of the Collective Security Operational Forces (CORF) established in June 2009 in the frame of the Collective Security Treaty Organization (CSTO) has been a reflection of growing Russian military presence on the CIS territory as well as Moscow's aspirations to create a NATO-alike body to monopolize the security cooperation in the region. Yet the absence of two crucial members of the CSTO - Belarus and Uzbekistan significantly diminished the propaganda success of the inaugural CORF summit in Moscow (McDermott, 2009). The lack of effectiveness of Russian multilateral initiatives on the post-Soviet area has for a long time been a problem for the Russian foreign policy and the CIS Chisinau summit on August 2009 appeared a failure again as presidents of Kazakhstan, Tajikistan, Turkmenistan and Uzbekistan refused to participate and Georgia formally completed the procedure of its withdrawal from the Commonwealth (Coalson, 2009).

Indeed, there have been several countries on the area of the CIS able to demonstrate their real independence of Russia and despite the case of Ukraine, that has openly criticized the Russian intervention in Georgia, this refers especially to two important members of the "southern flank" of the CIS - Turkmenistan and Uzbekistan. The Uzbek foreign policy has usually been reflecting the periods of rapprochement alternately with Russia and the United States, yet the Tashkent dissatisfaction with Moscow's divide and impera policy on the area of the CIS after the war in Georgia and reluctance to growing Russian military presence in Central Asia have resulted in a 
significant reduction of Uzbek contacts with Moscow. As a result Tashkent has not supported any new ideas of regional cooperation inspired by Russia and it has again been looking for a possibility of closer political dialogue with Washington and Brussels. This time, however, Uzbekistan has focused on strengthening its contacts with Beijing - reflected by the growing Uzbek economic ties with China. They include the Chinese interest in independent of Russia energy and transport corridors developed in cooperation with Tashkent as well as Chinese investments in Uzbek industries exceeding \$2 billion in the period 2005-2010 (Weitz, 2011; Pannier, 2009c).

China has also become an important economic partner in the case of Turkmenistan that has been facing a Moscow's pressure to reduce the price of the Turkmen gas bough by Russia and exported through the Russian pipelines to the EU. The Turkmen-Russian relations entered a period of additional tensions after the April 2009 damage of the pipeline connecting both countries, halting the Turkmen gas export and depriving the country most of its budget incomes (Lobjakas, 2009b). Yet the Moscow's pressure has largely been ineffective as Turkmenistan has immediately begun the talks on diversification of the export routes with Beijing. The most important in this regard has been the opening of the new Turkmen-Chinese pipeline (crossing the territory of Kazakhstan and Uzbekistan and bypassing the territory of Russia) as well as a Chinese \$4billon loan for Ashkhabad helping to stabilize Turkmen finances. Thus, even after the renewal of the Turkmen gas export through the Russian pipelines Ashkhabad has retain the ability to diversify its export routes (Jarosiewicz, 2009; RFE/RL News, 2009b) and Beijing's direct support for both Central Asian republics illustrates growing significance of China as the key regional actor.

As a result, the effectiveness of the Russian efforts to tighten its control over the countries of the CIS after the war in Georgia seems to be limited. Some of the CIS republics, but especially those dependent on Russia before (like for example Kyrgyzstan, Tajikistan and Armenia) have indeed been more subordinated to the Russian interests, but some of the CIS members have been able to mark their growing independence of Moscow's foreign policy. The Russian military intervention in Georgia has in fact caused the anxiety and cautiousness among the Commonwealth's members, strengthening the Moscow's position there in a short term, yet in the medium perspective Russia will certainly face resistance, especially in the case of the countries in the region able to establish independent of Russia economic contacts with other regional powers. Their main economic (and prospectively political) partner becomes China and it is quite illustrative that the Shanghai Cooperation Organization (SCO), that includes Russia, China and some post-Soviet Central Asian republics, has formally refused to support Russia's intervention in Georgia and to recognize Abkhazia and South Ossetia as well. Stephen Blank indicates in this context that China "has intentionally remained silent, indicating its ambivalence (...)", the CSO has appeared not to be the rubber stamp in the hands of Russia and the Organization's reactions have clearly pointed out that "China has more influence in the SCO than Moscow would like it to have" (Blank, 2008).

Beijing has in fact been deeply interested in a stable access to Central Asian natural resources as well as in economic ties with the countries of the region, expressing its readiness to invest several billions of dollars to support common energy infrastructure and to assist post-Soviet Central Asian economies with loans. Even if the consequences of the Chinese engagement in the post-Soviet Central Asia may not considerably deteriorate the Russian-Chinese relations Russia is certainly going to face growing Chinese influence over the area that is not limited to Uzbekistan or Turkmenistan. Kyrgyzstan or even Belarus demonstrative will to expand their economic this with China clearly illustrate this tendency. Besides, Moscow has so far had a lot of experience in dealing with the US and the EU's "interference" in the post-Soviet area, taking advantage of the lack of the common European policy, specific European "political correctness" in relations with Moscow as well as the US focus on the global problems. Yet the China's economic potential, its growing interests in cooperation with post-Soviet Central Asia and possible lack of similar "correctness" in the policy of Beijing will most probably face Moscow with much more difficult challenges.

\section{Russia's game for its geostrategic position - the relations with the United States and the European Union}

Facing the Russian military intervention in Georgia the West has reacted cautiously and both the United States and the EU have proved to be unwilling to respond to it more decisively. Cornell, Popjanevski and Nilsson indicate in this context that the Western states have not been able to foresee Russia's intervention despite some indications prior to the conflict and the Western leaders finally failed to prevent Russia from ignoring the terms of cease-fire agreements. They also warn that "Internal divisions in the EU and NATO, and a weakened U.S. administration, all combined to provide Moscow with what it perceived as a low-risk opportunity to punish Georgia for its independent policy (...)" (Cornel, Popjanevski \& Nilsson, 2008). 
The Western powers have been talking about sanctions against Russia, yet facing Moscow's determination the effectiveness of the Western political pressure on Russia has been limited. Moscow has quickly dismissed the European threats of freezing the EU's cooperation with Russia as well as the US warnings of ruling Russia out of the G-8 and some other forums of international dialogue. On the contrary, Moscow itself has been signaling a will to reconsider its cooperation with some international organizations, including its negotiations on joining the WTO. Russia has at the same time intensified its contacts with OPEC and it has supported an idea of establishing the OPEC-alike organization to coordinate the export policies of gas-exporting countries. Although the effectiveness of such the organization would be disputable and any coordination has in fact not been in the Russian interests the threat of the common policy among the gas exporters has contributed to growing anxiety in the West (RFE/RL News, 2008).

Furthermore, Russia has been fully aware that the war in Georgia has brought about a lot of political problems not only for Moscow but also for its Western partners. In the case of the European Union the war has inflamed the previous debates and disagreement on the Union's policy towards Russia and in the case of the United States Moscow has been aware of potential difficulties unfavorable Russian policy may cause to the US transit to the coalition forces in Afghanistan. The prospects of Russia disrupting the stability of supplies for the US troops in Afghanistan have been warning enough to convince Washington that the sharp US-Russian confrontation over the war in Georgia is too hazardous for the US global interests.

In fact, the United States and the EU have soon decided to quit the rhetoric of isolation and to come back to "business as usual" relations with Russia. Although some observers, including Stephen J. Blank, indicate that the intervention in Georgia has contributed to growing impression in the West that Russia is no longer a reliable partner to do business with (Blank, 2008), it has been clear that more effective Western response would require more determination and more readiness to directly confront the policy of Moscow. The West has lacked them both. Besides, both sides have so far invested a lot in a network of their contacts and Russia has been more and more sure that the West would not risk it for Georgia. Thus, facing a "thaw" in the policy of the West but first of all the world economic crisis striking Russian economy Moscow has become much more interested in a possible "reset" of relations proposed by the President Obama's administration.

The Russian will to "reset" in its relation with the West, however, remains conditional and Moscow has been demanding the US respect for Russia's global role and interests, to include the Russian opposition to the US project of anti-missile shield to be installed in Poland and Czech Republic, Moscow's reluctance to further NATO enlargement as well as the US recognition of the Russian "special position" on the area of the CIS (Tsygankov, 2009). Instead, Moscow has been declaring its readiness to support Washington in solving the international problems crucial for the US interests, including the transit of coalition troops to Afghanistan and the case of the Iranian nuclear program.

Some analysts, however, have been indicating that the value of the Russian offer has been limited. They point out that the Russian policy towards Iran still remains unclear as Teheran has so far been an important Moscow's trade partner and tactical ally in Russian political games aimed at limiting the global influence of the United States (Kaczmarski, 2009). Although Russia is not interested in Iran having a nuclear bomb and Teheran may potentially be a future Moscow's rival in Central Asia the economic benefits from the nuclear energy cooperation as well as military contracts with Iran still remain a valid factor in the Moscow's foreign policy. As a result, it is still difficult to expect a fundamental change in the Russian policy towards Iran and Moscow may well pretend a tougher policy to meet the US expectations. Besides, it is clear that Russia would insist on a concrete political price for its new policy towards Teheran, irrespective of its real results. In fact, the review of the recent Moscow's position on the Iranian nuclear program has clearly illustrated Russia's hesitation and maneuvering between the US pressure to join the UN sanctions and Moscow's engagement in activation of the Busher nuclear plant as well as Kremlin's determination to continue profitable military cooperation with Teheran (RFE/RL News, 2010a,b,c).

One of the crucial aspects of the Russian price for further cooperation has been the Washington's decision to resign the permanent elements of the anti-missile shield to be deployed in Poland and the Czech Republic and to replace them by mobile components. Although Russia seems to be aware that the new concept might even be more effective than the previous one the President's Obama decision has been presented by Moscow as a Russian victory and an example of the US respect for the Russia's international interests. The decision, however, has contributed to East-Central European fears that the new US attitude towards Moscow may weaken Washington's relations with this part of Europe. They were expressed by the letter of the leaders of East-Central European states urging Washington not to lose its ties with the region (An Open Letter, 2009). It is clear that the problems of Iranian nuclear program and the need of global cooperation with Russia are much more important 
for the US administration yet it seems that the East-Central European intention has simply been to ask whether Washington has not overestimated the real value of the Russian cooperation?

Indeed, a lot of analysts indicate the need of cooperation with Russia. Roman Muzalevsky contends in this context that facing the world financial crisis and the results of the August war the West should not alienate Moscow but rather try to provide Russia with a larger responsibility for the international system (Muzalevsky, 2009). Olga Oliker, Keith Krane, Lowell H. Schwartz and Catherine Yusupov point out at the same time that the truly hostile Russia would make some serious problems to US global goals and "A reversal of Russian policy toward proliferation in Iran and Korea would signal these and other countries that, as far as the Russian government is concerned, nuclear weapon programs can be developed with impunity" (Oliker \& Krane et al., 2009). Nevertheless the same four authors indicate that the aims of fighting global threats (including the war with terror and the problems of nonproliferation), in which the United States has been looking for the Russian cooperation, are important but lower priorities for Moscow and Russia have usually seen them as the questions more of a favor to Washington (Oliker \& Krane et al., 2009). Thus, there is still a question whether the West would react adequately enough facing Russia simulating its support for the Western efforts to solve the global problems. Cornell, Popjanevski and Nilsson seem to be quite right to point out that the Western failure to attach serious political costs to the Russian intervention in Georgia may create an impression of permissiveness in Moscow and may potentially draw it to the conclusion that the use of force to achieve its interests is useful (Cornel, Popjanevski \& Nilsson, 2008).

Considering the Russian cooperation with the European Union the first EU-Russia summit after the war in Georgia, taking place on May 22, 2009 in Khabarovsk, pointed out that both sides differ in their opinions in almost all areas of cooperation (Lobjakas, 2009a). Yet the next years' meetings have considerably changed the rhetoric to "constructive" and "newly pragmatic" and both sides have been avoiding difficult topic of the Russian-Georgian conflict (Lobjakas, 2010). In fact, the war has confirmed differences within the European Union with regard to the policy on Russia - with East-Central European warnings of the Russian neo-imperialism and Western reluctance to use more restrictive measures in reaction to Moscow's intervention in Georgia. Besides, Russia has always been playing a card of the EU internal divisions investing a lot in bilateral contacts with the leading EU countries, including Germany, France and Italy. Thus, facing the lack of cohesiveness as well as the game of national interests within the European Union the common position of the EU on Russia is going to be mild and the European diplomatic impact on the Moscow's foreign policy will certainly be limited.

Considering the future of the Western-Russian relations it seems that despite the tensions accompanying the war in Georgia the common interests and the need of cooperation have prevailed over the dispute. In fact, it would be useless to ignore and isolate Russia while dealing with the most difficult global issues. In many cases it is simply impossible (the case of the US transit to Afghanistan) and in some others Moscow indeed may be an important and valuable partner. Nevertheless, it is still unclear whether the Western powers would be able to react cohesively and decisively enough once another Georgian-alike crisis happened again. Besides, Stephen J. Blank points out that the Russian intervention in Georgia has in practice been an attempt to ruin the international order Moscow has been benefitting no less than the West (Blank, 2008). Thus, it seems that the lesson of the Georgian war should be learned not only by the West but by Moscow as well.

\section{Conclusions}

The assertive and great-power foreign policy of Russia during the second presidential term of Vladimir Putin has resulted in the Russian military intervention in Georgia. The aim of the intervention has been to demonstrate the Moscow's determination to keep the area of the CIS as the zone of the Russian "exclusive" interests and Kremlin has decided to risk its relations with the West to this end.

Intervening in Georgia Moscow has strengthened its position on the area of the CIS, at least in the short term. It doesn't mean, however, that the Russian victory has been full and spectacular as Moscow has been able to additionally subordinate mainly the members of the CIS dependent on Russia before. Moreover, Kremlin has faced the serious resistance of many post-Soviet Central Asian republics striving for establishing alternative economic ties with other regional powers, and mainly with China. In fact, the war in Georgia has activated other regional actors, including Turkey and China, and growing Beijing's interest in strengthening its economic (and possibly political) contacts with post-Soviet Central Asia is going to face Moscow with new challenges in the region.

In the case of the West the Western reactions to the conflict have generally confirmed Russia's assumptions that the United States and the European Union would not sacrifice their previous network of contacts and cooperation 
with Moscow for Georgia. The Western diplomatic pressure on Kremlin has appeared to be mild and limited, illustrating serious problems with the cohesive and decisive response, especially in the case of the EU. The Western powers have lost a lot of their previous image among the CIS states and in fact it has only been the world economic crisis that has seriously affected the dynamism of the Russian foreign policy. The calculation of the common global interests has finally contributed to the United States' and the EU's will to come back to "business as usual" relations with Russia. Yet despite the "reset" in the Western-Russian relations the lack of cohesiveness and limited ability to formulate clear expectations towards Moscow remain a serious problem for the Western powers and it seems that the West would still have troubles with effective reaction once another Georgian-alike crisis happened again.

\section{References}

An Open Letter to the Obama Administration from Central and Eastern Europe. (2009). Gazeta Wyborcza, 16 July. [Online] Available: http://wyborcza.pl/1,76842,6825987, An_Open_Letter_to_the_Obama_Administration_from_Central.html (February 2011)

Blank, S. J. (2008). Georgia: The War Russia Lost. Military Review, November-December, 39-40, 42-43, 45.

Blua, A. (2010). Russia Signs Deal To Build Turkey's First Nuclear Power Plant. RFE/RL News, May 12.

Coalson, R. (2009). What If The CIS Holds A Summit, And No One Comes? RFE/RL Features, October 7.

Cornell, S.E., Popjanevski, J. \& Nilsson, N. (2008). Russia's War in Georgia: Causes and Implications for Georgia and the World. Policy Paper, August, Central Asia-Caucasus Institute \& Silk Road Studies Program. John Hopkins University/Institute for Security and Development Policy-Stockholm, Sweden, 4, 24, 26, $28,32$. [Online] Available: http://www.silkroadstudies.org/new/docs/silkroadpapers/0808Georgia-PP.pdf (February 2011).

Falkowski, M. (2009). Turkey's game for the Caucasus. Centre for Eastern Studies (OSW) Commentary, No. 29, October 5.

Gorecki, W. (2009). Russia and Turkey intensify co-operation. OSW Eastweek, No. 7(157), February 18, 5-7. (2009). Independent International Fact-Finding Mission on the Conflict in Georgia, Report, September 2009. [Online] Available: http://news.bbc.co.uk/2/shared/bsp/hi/pdfs/30_09_09_iiffmgc_report.pdf Jarosiewicz, A. (2009). China joins the Turkmen-Russian gas conflict. OSW Eastweek, No. 24(174), July 1, 2-3. Kabadze, D. \& Vashakmadze, M. (2009). After Russia-Georgia Report, A Sense Of 'What Now'? RFE/RL Features, October 6.

Kaczmarski, M. (2009). Iran's position in Russia's foreign policy and Russian-American relations. OSW Commentary, No. 24, April 15.

Karmanau, Y. (2010). Russia helped rout leaders: Kyrgyz rebels. The Sydney Morning Herald, April 10. [Online] Available:

(February 2011).

Kononczuk, W. (2009). Russia uses the crisis to build influence in CIS countries. OSW Eastweek, No. 6(156), February 11, 2-3.

Lobjakas, A. (2009a). At EU-Russia Summit, Signs Of Strategic Division, Not Strategic Partnership. RFE/RL Features, May 22.

Lobjakas, A. (2009b). Pipeline Explosion Raises Tensions Between Turkmenistan, Russia. RFE Features, June 4. Lobjakas, A. (2010). EU-Russia Summit To Steer Forward Course, Without Rocking The Boat. RFE/RL Features, May 30.

McDermott, R. (2009). CSTO Rapid Reaction Exercises Get Off To Discouraging Start. RFE/RL Commentary, August 27.

Mitchell. (2009). Discussion of Lincoln Mitchell and Edward Lucas moderated by RFE/RL Georgian Service, published in: Roundtable: Causes And Effects Of The Russia-Georgia War. RFE/RL Commentary, August 8.

Muzalevsky, R. (2009). The War in Georgia and its Aftermath: Russian National Security and Implications for the West. Review of International Law and Politics, 19, 115, 123. 
Nichol, J. (2009). Russia-Georgia Conflict in August 2008: Context and Implications for U.S. Interests. CRS Report for Congress. Congressional Research Service, March 3, 13-15. [Online] Available: http://www.fas.org/sgp/crs/row/RL34618.pdf

Nygren, B. (2007). Putin's Attempts to Subjugate Georgia: From Sabre-Rattling to the Power of Purse. In R. E. Kanet (ed.). Russia: Re-Emerging Great Power (pp. 107-108). Houndmills, Basingstoke, Hampshire and New York: Palgrave Macmillan.

Oliker, O., Krane, K., Schwartz, L.H., \& Yusupov, C. (2009). Russian Foreign Policy. Sources and Implications. Santa Monica, Arlington, Pittsburgh: RAND Corporation, 175-178, 183, 194-195.

OSW Eastweek (2008). No. 30(64), September 24. OSW Eastweek (2009). No. 4(79), January 28.

Pannier, B. (2009a). Security Concerns Rising As Arctic Thaw Spurs Race For Oil. RFE/RL Features, January 29.

Pannier, B. (2009b). U.S., Kyrgyzstan Reportedly Draft New Deal On Manas. RFE/RL News, June 23.

Pannier, B. (2009c). Russia Facing Resistance With Allies On CIS's Southern Flank. RFE/RL Features, October 09.

Recknagel, Ch. (2009). Putin Wins Turkey's Approval Of South Stream Route. RFE News, August 6. RFE/RL News (2008). Russia Says Gas Forum Will Not Be OPEC-Like Cartel, December 23. RFE/RL News (2009a). China, Russia Bolster Ties With \$3.5 Billion In Deals, October 13. RFE/RL News (2009b). Turkmenistan To Restore Gas Supplies To Russia, December 22. RFE/RL News (2010a). Russia Urges Iran To Cooperate On Nuclear Issue, February 19. RFE/RL News (2010b). Russia Says New Sanctions Won't Affect Missiles Sale To Iran, June 10. RFE/RL News (2010c). Russia Says New EU Sanctions Against Iran 'Unacceptable', July 27.

Sindelar, D. (2008). Feeling Expansive, Moscow Looks To U.S. 'Backyard', Latin America. RFE/RL Features, October 09.

Sindelar, D. (2009). 2008 In Review: Was This The Year That Russia Peaked? RFE/RL Features, January 03.

Strachota, K. (2008). The Southern Caucasus and Central Asia after the Russian-Georgian war - the geopolitical consequences. OSW Commentary, No. 10, September 25.

Tsygankov, A. (2009). Asymmetrical Expectations In Washington And Moscow. RFE/RL Commentary, February 28.

Weitz, R. (2011). Uzbekistan's Growing Role in Beijing's Central Asian Strategy. The Jamestown Foundation, January $14 . \quad$ [Online] Available: http://www.jamestown.org/programs/chinabrief/single/?tx_ttnews[tt_news] $=37370 \&$ cHash=972fb74c75 (February 2011).

Whitmore, B. (2010). Moscow Visit By Turkish PM Underscores New Strategic Alliance. RFE/RL Features, January 12 . 